\title{
Influence of soybean seed moisture content in the response to seed treatment in soybean
}

\author{
Marcos Altomani Neves Dias ${ }^{1}$, André Kitaro Mocelin Urano ${ }^{1}$, Deborah Bueno da Silva ${ }^{1}$, Silvio \\ Moure Cicero ${ }^{1}$
}

${ }^{1}$ University of São Paulo/ESALQ, São Paulo, Brasil. E-mail: marcosaltomani@gmail.com, uranokitaro@gmail.com, debora.bueno.silva@usp.br, smcicero@usp.br

Recebido: 03/01/2017; Aceito: 21/02/2018

\section{RESUMO}

Seed treatment (ST) is an important practice for soybean crop. This research had the objective to evaluate the influence of seed moisture content in the response to different spray volumes (SV) used for seed treatment in soybean, considering effects on seed physiological quality. Three seed lots with distinct moistures were used: $7.2 \%, 10.1 \%$ and $13.0 \%$. Untreated seeds (control) and three SV were tested: 8,13 and $18 \mathrm{~mL} \mathrm{~kg}^{-1}$. All lots received the same treatment combination, containing insecticide, fungicide, fertilizer and biostimulant. This combination represented $8 \mathrm{~mL} \mathrm{~kg}^{-1}$ of SV; the doses of 13 and $18 \mathrm{~mL} \mathrm{~kg}^{-1}$ were obtained by adding 5 and $10 \mathrm{~mL}$ $\mathrm{kg}^{-1}$ of water, respectively. Evaluations of seed physiological quality consisted of electrical conductivity, seed respiration, germination and vigor tests. Results of all tests demonstrates that low-moisture soybean seeds (7.2\%) are negatively affected by seed treatment within an SV range of 8 to $18 \mathrm{~mL} \mathrm{~kg}^{-1}$, while untreated seeds with equal moisture are not affected. Oppositely, high-moisture seeds (13.0\%) are not affected by the SV tested, while intermediate-moisture seeds $(10.1 \%)$ are affected by the higher SV. This result highlights seed moisture as a key parameter to be managed before soybean ST, aiming to maintain a high physiological quality.

Key words: seed coating, seed conditioning, seed quality, seed vigor

\section{Influência do teor de água das sementes na resposta ao tratamento de sementes em soja}

\begin{abstract}
O tratamento de sementes (TS) é uma prática importante para a cultura da soja. O objetivo deste trabalho foi avaliar a influência do teor de água das sementes de soja na resposta a diferentes volumes de calda (VC) no TS, considerando efeitos na qualidade fisiológica das mesmas. Foram utilizados três lotes de sementes com diferentes teores de água: 7,2\%, 10,1\% e 13,0\%. Sementes não tratadas (controle) e três VC foram testados: 8,13 e $18 \mathrm{~mL}$ $\mathrm{kg}^{-1}$. Todos os lotes receberam a mesma combinação de inseticida, fungicida, fertilizante e bioestimulante, que representou $8 \mathrm{~mL} \mathrm{~kg}^{-1}$ de VC; as doses 13 e $18 \mathrm{~mL} \mathrm{~kg}^{-1}$ foram obtidas pela adição de 5 e $10 \mathrm{~mL} \mathrm{~kg}^{-1}$ de água, respectivamente. As avaliações da qualidade fisiológica das sementes consistiram em testes de condutividade elétrica, respiração de sementes, germinação e vigor. Os resultados indicam que sementes de soja com baixa umidade $(7,2 \%)$ são afetadas negativamente pelo TS com VC entre 8 e $18 \mathrm{~mL} \mathrm{~kg}^{-1}$, enquanto sementes não tratadas com mesma umidade não são afetadas. Em contrapartida, sementes com alta umidade $(13,0 \%)$ não são afetadas pelos VC testados, enquanto sementes de umidade intermediária $(10,1 \%)$ são afetadas apenas pelos maiores volumes. Este resultado destaca a umidade da semente como parâmetro fundamental a ser administrado antes do TS de soja, com o objetivo de manter alta qualidade fisiológica.
\end{abstract}

Palavras-chave: revestimento de sementes, beneficiamento de sementes, qualidade e vigor de sementes. 
Soybean [Glycine $\max$ (L.) Merr.] crop area in Brazil is estimated in 34 million hectares for the 2016/2017 season (CONAB, 2016). This amount of land requires approximately 2 million tons of soybean seeds, which represents 3.7 billion BRL or $37 \%$ of Brazilian seed market (ABRASEM, 2015). This large amount of seed is expected to be managed within a wide amplitude of environmental conditions during transport and storage.

Seed moisture content is an important parameter to be managed during storage. Maximum seed quality is achieved yet in the field, at physiological maturity stage (BEWLEY; BLACK, 2013). Afterwards, the longevity or period of viability of seeds is directly linked to their moisture content, which depends on the temperature and relative humidity of the storage environment (MBOFUNG et al., 2013). Particularly in Brazil, where a large part of soybean seeds is produced and stored in tropical regions, efforts towards reducing the temperature of seed batches and also the moisture content of seeds are becoming more common (DEMITO; AFONSO, 2009; ZUCHI; LACERDAFILHO, 2011; ZUCHI et al., 2013; VIRGOLINO et al., 2016).

After storage, soybean seeds generally receive a chemical or biological treatment with liquid formulations. In Brazil, more than $90 \%$ of soybean seeds that is used in the field contain a certain type of treatment (FRANÇA-NETO et al., 2015), with the operation being executed either in large (industrial) or small scale ("on-farm"). Currently, the components that are predominantly applied to seeds are: fungicides, insecticides, nematicides, micronutrients, microbial inoculants, biostimulants and polymers, with most of them being applied as liquid; water is also commonly added.

The spray volume used for seed treatment is mainly determined by two factors: 1) the dose of a given component that needs to be applied to be effective and 2) the amount of liquid that is necessary to promote a uniform coverage of the seed coat and, consequently, a uniform distribution of the applied compounds among seeds (SCOTT, 1998). In the case of soybean, it was verified from several sources, such as Henning et al. (2010), Segalin et al. (2013), extension communications from Embrapa Soybean (Brazilian Agricultural Research Corporation) and personal communications, that a wide range of seed spray volume is currently being used, generally ranging from 6 to $15 \mathrm{~mL} \mathrm{~kg}^{-1}$ of seed.

In this context, this study was carried out to verify the direct influence of soybean seed moisture content in the response to different spray volumes used for seed treatment.
Seed lots: a seed lot of soybean cultivar RK7214IPRO, initially stored in cold chamber $\left(20{ }^{\circ} \mathrm{C}\right.$; $45 \%$ R.H.), with $8.1 \%$ of moisture content and $215.6 \mathrm{~g}$ of a thousand-seed weight, was used to form three distinct seed lots, with moisture contents of $7.2 \%$ (L7), $10.1 \%$ (L10) and $13.0 \%$ (L13). Seed moisture was adjusted using a dry weight basis, previously determined to obtain the desired moisture levels. L7 was obtained by drying in an air-forced oven, at $33{ }^{\circ} \mathrm{C}$. Lots L10 and L13 were obtained by placing the seeds upon a wire mesh inside acrylic boxes with lid, containing 40 $\mathrm{mL}$ of distilled water (100\% R.H.), maintained at $20{ }^{\circ} \mathrm{C}$ in a BOD incubator; during these processes, seeds were frequently weighed until reached the desired moisture.

Seed moisture content: determined with two $15 \mathrm{-g}$ samples per seed lot, oven dried at $105 \pm 3{ }^{\circ} \mathrm{C}$ for $24 \mathrm{~h}$, following the procedure described on Brasil (2009).

Electrical conductivity and seed respiration tests were carried out with untreated seeds, presenting 7.2, 10.1 and $13.0 \%$ of moisture. These tests aimed to characterize the lots in terms of physical and physiological aspects of seeds.

Electrical conductivity (EC): conducted with four replicates of 50 seeds per treatment. Seeds were first immersed in $75 \mathrm{~mL}$ of deionized water and maintained at $25{ }^{\circ} \mathrm{C}$ for $24 \mathrm{~h}$ (ISTA, 2006). After this period, the electrical conductivity in the water was determined using a conductivity meter Digimed CD-20, with results expressed in $\mu \mathrm{mho} \mathrm{cm}^{-1} \mathrm{~g}^{-1}$.

Seed respiration (SR): assessed through an acidbase titration method, with three replicates per lot. Seeds $(50 \mathrm{~g})$ were placed in mason-type jars with lids; $10 \mathrm{~mL}$ of $\mathrm{NaOH} 1 \mathrm{M}$ were added in plastic vials and placed inside the jars (upon the seeds) before closing; three jars containing only these vials (with $10 \mathrm{~mL}$ of $\mathrm{NaOH} 1 \mathrm{M}$ ) were included as blank standards. The jars were maintained at room temperature, for 21 days. Afterwards, $1 \mathrm{~mL}$ of a $50 \% \mathrm{BaCl}_{2}$ solution and two drops of phenolphthalein were added to each pot containing $10 \mathrm{~mL}$ of $\mathrm{NaOH} 1 \mathrm{M}$, and they were titrated with $\mathrm{HCl} 1 \mathrm{M}$ to calculate the amount of $\mathrm{CO}_{2}$ released by seeds during the period, which is directly associated to the amount of $\mathrm{OH}^{-}$consumed in the titration.

Seed treatment: seeds were treated right after the desired moisture level was reached. They were coated with the recommended doses of commercial products commonly applied as soybean seed treatment, composed of insecticide, fungicide, micronutrients and biostimulant. The products together totaled $8 \mathrm{~mL}$ of spray volume, and added the following components to the seeds: fipronil $\left(0.5 \mathrm{~g} \mathrm{~kg}^{-1}\right)$, thiophanate-methyl $(0.45$ $\left.\mathrm{g} \mathrm{kg}^{-1}\right)$; pyraclostrobin $\left(0.05 \mathrm{~g} \mathrm{~kg}^{-1}\right)$, copper $\left(0.44 \mathrm{~g} \mathrm{~kg}^{-}\right.$ $\left.{ }^{1}\right)$, molybdenum $\left(0.28 \mathrm{~g} \mathrm{~kg}^{-1}\right)$, zinc $\left(2 \mathrm{~g} \mathrm{~kg}^{-1}\right)$ and seaweed extract ( $0.1 \mathrm{~g}$ dry mass). 
Seeds were treated in a stainless-steel pan coater equipped with a rotating motor (Leroy-Somer, model LS71 $0.75 \mathrm{KW}$ ), containing a conical spreader in the center. Three spray volumes were evaluated: 1) $8 \mathrm{~mL}$ $\mathrm{kg}^{-1}$ (8 mL of products), 2) $13 \mathrm{~mL} \mathrm{~kg}{ }^{-1}$ (8 mL of products $+5 \mathrm{~mL}$ of water) and 3) $18 \mathrm{~mL} \mathrm{~kg}^{-1}$ (8 mL of products $+10 \mathrm{~mL}$ of water); a control treatment with no liquid added was also included. After treatment, seeds were placed in paper bags and stored at room conditions $\left(24.6 \pm 3.0{ }^{\circ} \mathrm{C} ; 55 \%\right.$ R.H.). Fourteen days after seed treatment, seeds were submitted to the following tests

Germination (G) and first count of germination (FCG): four replicates of 50 seeds per treatment were placed in rolled paper towels (Germitest), containing three sheets of paper each, previously moistened with water to 2.5 times the weight of the dry paper. The rolls were maintained in a germination chamber at $25{ }^{\circ} \mathrm{C}$. The first (FCG) and second (G) germination counts occurred at the $5^{\text {th }}$ and $8^{\text {th }}$ days after sowing, respectively, according to Brasil (2009).

Seedling emergence in the field (FE): four replicates of 100 seeds per treatment were sown in 5-m rows, in a field with clay texture soil (65\% clay). Sprinkler irrigation was used. Seedling emergence count occurred on the $7^{\text {th }}$ and $14^{\text {th }}$ days after sowing. Average temperature during the 14-day period of testing was $25.3{ }^{\circ} \mathrm{C}$, with $19.4{ }^{\circ} \mathrm{C}$ and $33.5{ }^{\circ} \mathrm{C}$ of minimum and maximum temperatures, respectively.

Seedling emergence (SE) and speed of emergence (SSE) in sand: four replicates of 50 seeds per treatment were sowed in $0.47 \times 0.35 \times 0.11 \mathrm{~m}$ plastic trays, filled with $8 \mathrm{dm}^{3}$ of fine sand (moistened to $60 \%$ of the water holding capacity). The trays were maintained in greenhouse, with a mean temperature of $25 \pm 4{ }^{\circ} \mathrm{C}$ during the evaluation period. Emerged seedlings were counted daily to calculate the speed index of seedling emergence, according to Maguire (1962). Final emergence was counted on the $9^{\text {th }}$ day after sowing.

Seedling emergence (SEa) and speed of emergence (SSEa) of aged seeds: the test was conducted following procedure described in AOSA (2009). A single layer of soybean seeds was placed on a wire mesh in a $11 \times 11 \times 3.5 \mathrm{~cm}$ acrylic box with lid, containing $40 \mathrm{~mL}$ of distilled water. The boxes were maintained at a temperature of $41{ }^{\circ} \mathrm{C}, 100 \%$ R.H, for 48 hours. Afterwards, seedling emergence in sand was conducted following the same procedure described for SE and SSE.

Statistical analysis was performed using the $\mathrm{JMP}^{\circledR}$ Statistical Software (SAS Institute, version 10). A factorial design $3 \times 4$ was used, with two factors: seed moisture content (3) and seed spray volume (4). Data was first submitted to analysis of variance and, in case of significance $(\mathrm{P}<0.05)$, means were compared by Tukey's test.
Seed moisture content of seeds was monitored after treatment (untreated seeds were also monitored concomitantly). At the moment of treatment, seed lots L7, L10 and L13 presented mean values of 7.2\%, 10.1\% and $13.0 \%$ of seed moisture content, respectively. In the next day, 24 hours after treatment, the moisture content of seeds increased for L7 and decreased for lots L10 and L13, with mean values of $8.1 \%, 10.0 \%$ and $12.4 \%$, respectively. Fourteen days after treatment the lots reached an equilibrium of seed moisture content, with a mean value of $9.7 \%$; untreated seeds presented the same values of treated seeds.

Results of electrical conductivity (EC) and seed respiration (SR) are presented on Figure 1. These tests provided a characterization of seed lots at the moment of seed treatment. The EC increased as the water content of seeds decreased, with EC value of L7 being approximately $65 \%$ higher than L13. The mean EC values for lots L7, L10 and L13 were 82.4, 65.5 and $50.0 \mu \mathrm{mho} \mathrm{cm}^{-1} \mathrm{~g}^{-1}$, respectively. Oppositely, seed respiration increased as moisture content of seeds increased, with a twenty-fold increase of $\mathrm{CO}_{2}$ release from L7 to L13. The SR values for lots L7, L10 and L13 were $0.005,0.015$ and $0.102 \mathrm{mg} \mathrm{CO}_{2} \mathrm{~g}^{-1} \mathrm{day}^{-1}$, respectively.

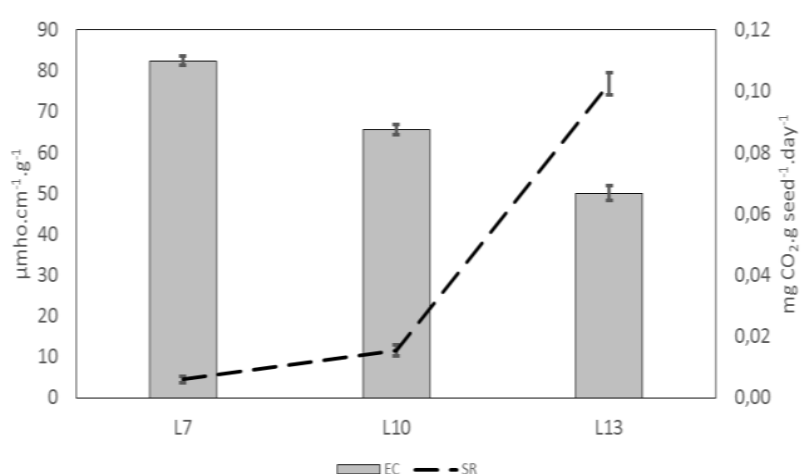

Figure 1. Results of electrical conductivity (EC) and seed respiration (SR) tests in soybean seeds, with lots presenting $7.2 \%$ (L7), $10.1 \%$ (L10) and $13.0 \%$ (L13) of seed moisture content. Bars corresponds to the Standard Error of the Mean

Figure 2 contains data of all seed quality parameters evaluated in the experiment after seed treatment. Results of first count of germination (FCG) and final germination $(\mathrm{G})$ presented a similar pattern, with no difference among L7, L10 and L13 for untreated seeds, while treated seeds varied in the response according to each spray volume applied. L13 did not differ from the control for any spray volume tested, while L10 differed only for the spray volumes of 13 and $18 \mathrm{~mL} \mathrm{~kg}^{-1}$; however, despite not statistically different, mean values for $8 \mathrm{~mL} \mathrm{~kg}^{-1}$ spray volume were considerably lower than the control, for both FCG and G results, decreasing from $98 \%$ (for both $\mathrm{G}$ and FCG of untreated seeds) to $85 \%$ and $90 \%$, respectively. 


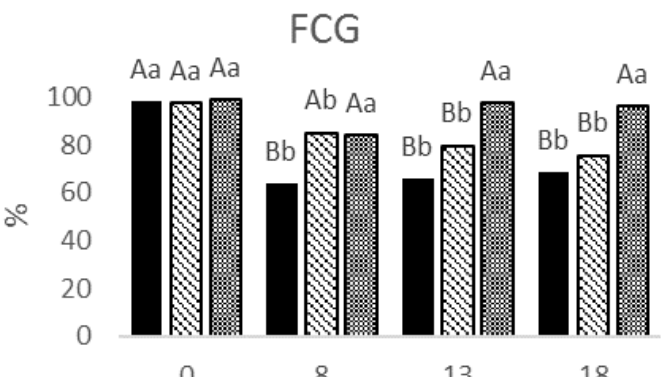

FE7d

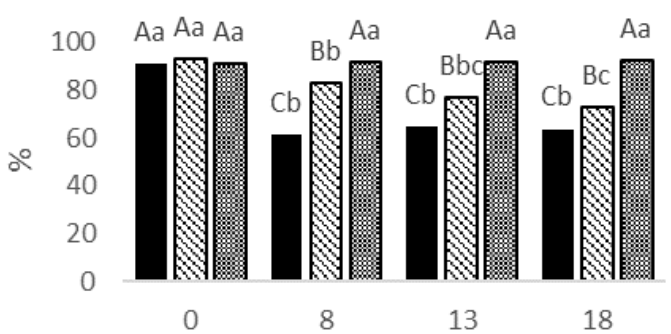

SE

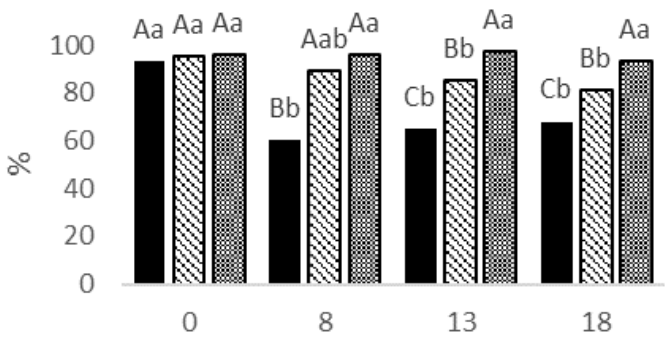

SSE

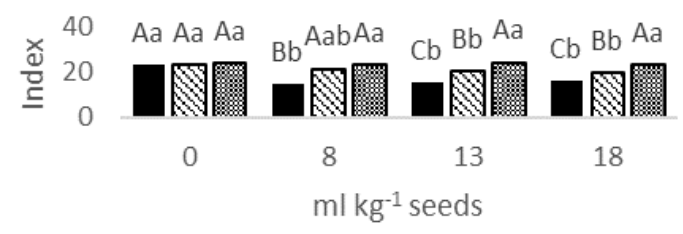

- $\mathrm{L7}$ \& L10 눙 L13
G

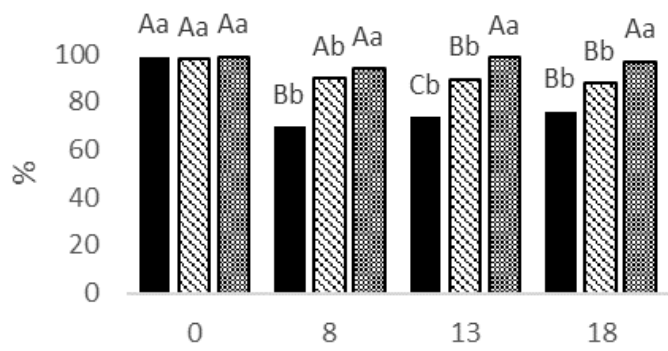

FE14d

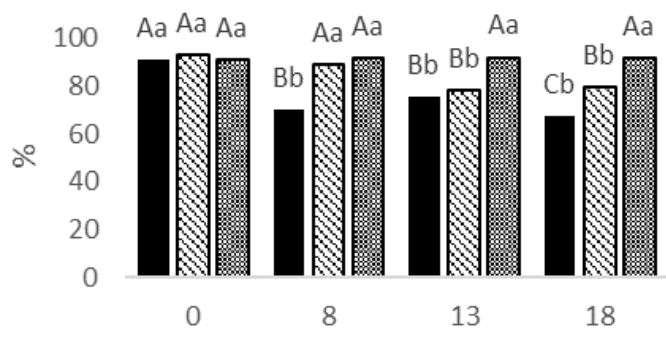

SEa

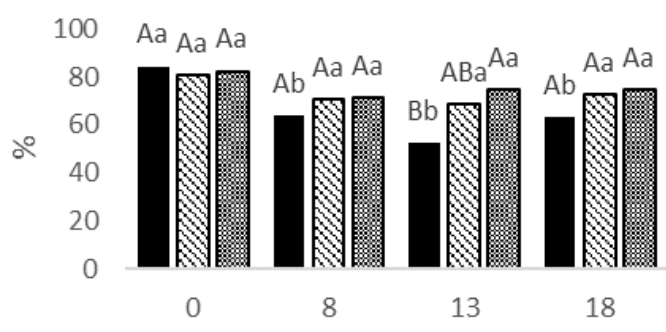

SSEa

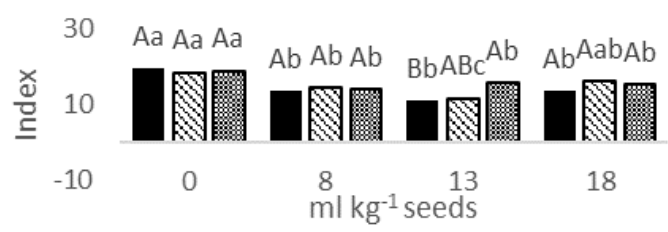

- $\mathrm{L} 7 \mathrm{\textrm {L }} 10$ 눙

Figure 2. Seed quality tests of soybean seeds with different moisture contents (L7:7.2\%; L10:10.1\%; L13: 13.0\%) and submitted to different spray volumes in the seed treatment $\left(0,8,13\right.$ and $18 \mathrm{~mL} \mathrm{~kg}^{-1}$ of seeds). First count of germination (FCG), germination (G), seedling emergence in the field at the $7^{\text {th }}$ (FE7d) and $14^{\text {th }}$ (FE14d) days after sowing, seedling emergence and speed of emergence in sand with normal (SE; SSE) and aged seeds (SEa; SSEa). *Different letters above the columns in the graph represent significant mean difference by Tukey test $(\mathrm{P} \leq 0.05)$. Uppercase letters compare among spray volumes within each seed moisture level; lowercase letters compare among seed moisture content within each spray volume.

In the case of L7, germination dropped from $99 \%$ of untreated seeds to $70 \%, 74 \%$ and $76 \%$ for spray volumes of 8,13 and $18 \mathrm{~mL} \mathrm{~kg}{ }^{-1}$, respectively. Seedling emergence in the field, counted at the $7^{\text {th }}$ and $14^{\text {th }}$ days after sowing, presented similar results for untreated seeds, with mean values ranging from 91 to 93\%. Treated seeds of L7 presented lower values compared to the control and to L13, for all spray volumes tested. Similarly, treated seeds of L10 also differed from the and L13 for all spray volumes applied, except $8 \mathrm{~mL} \mathrm{~kg}^{-1}$ evaluated at the $14^{\text {th }}$ day.

Results of seedling emergence in sand, for both aged (SEa) and non-aged seeds (SE), showed no difference among untreated seeds, with values ranging from 81 to $85 \%$ for aged and 93 to $96 \%$ for non-aged. For treated aged seeds, lots L7 and L10 were less prejudiced by the doses of spray volume if compared to field emergence and germination results. L10 and L13 did not differ 
from control at any dose, while L7 differed only for 13 $\mathrm{mL} \mathrm{kg}{ }^{-1}$. Likewise, the speed of seedling emergence (SSEa; SSE) was not affected in untreated seeds, while treated seeds presented variation in the results; for aged seeds, L10 and L13 were not affected at any dose, while for non-aged seeds, L10 was negatively affected at doses 13 and $18 \mathrm{~mL} \mathrm{~kg}^{-1}$. L7 was negatively affect only with the application of $13 \mathrm{~mL} \mathrm{~kg}^{-1}$ for aged seeds and 13 and $18 \mathrm{~mL} \mathrm{~kg}^{-1}$ for non-aged seeds.

Results of seed moisture analysis confirms the variation of soybean seed moisture content according to the environment, especially temperature and air relative humidity (MBOFUNG et al., 2013). At the $14^{\text {th }}$ day, treated and untreated seeds of all three lots had the seed moisture content at equilibrium, thus were considered appropriated to carry out the tests.

EC and SR tests allowed to verify the physical and physiological differences among seed lots at the moment of treatment. In the first test, a large variation of seed leachates could be verified among L7 and L13 seeds, with L10 being in an intermediate position. L7 presented considerably higher amounts of leachates, which represents an increased potential to be damaged when seeds are imbibed or even submitted to the application of liquids on their surface, as occurs during seed treatment (MATTHEWS; POWELL, 2006).

SR values also presented a wide range among lots, mainly comparing L7 and L10 to L13. Higher SR value, as verified on L13, represents lower seed longevity during storage. These two tests, EC and SR, allowed a good differentiation and characterization of the seed lots used in the study, in terms of physical and physiological properties.

The results obtained from all tests applied in this study presented a similar response pattern, with the seed lot containing lower moisture level (7.2\%) being prejudiced by the application of liquid treatments, both with "low" or "high" spray volumes. As previously verified, recommendations of spray volume for soybean seed treatment are generally in an interval of 6 to $15 \mathrm{~mL}$ $\mathrm{kg}^{-1}$ of seed. In this study, it was evaluated a range of 8 to $18 \mathrm{~mL} \mathrm{~kg}^{-1}$, and a negative response for low-moisture seeds $(7.2 \%)$ was negative to all of them. In the case of L10, with intermediate seed moisture content (10.1\%), there was a tendency to be harmed only by higher spray volumes (> $8 \mathrm{~mL} \mathrm{~kg}^{-1}$ ). The data also consistently demonstrates that seeds containing higher moisture $(13.0 \%)$ are not affected by any spray volume within the range tested.

Considering current crop management practices used for soybean in Brazil, especially in terms of pest and disease control and inoculation of $\mathrm{N}$-fixing bacteria, seed treatment plays a very important role in the production process. However, this technique must first meet the criteria to be safe to seeds, otherwise its use is not justifiable. Low-moisture soybean seeds (7.2\%) are negatively affected by treatment within a spray volume

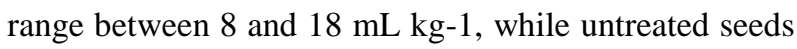
with equal moisture are not affected. Oppositely, highmoisture seeds $(13.0 \%)$ are not affected by the spray volumes tested, while intermediate-moisture seeds $(10.1 \%)$ are negatively affected only by the higher spray volumes (13 and $18 \mathrm{~mL} \mathrm{kg-1).} \mathrm{This} \mathrm{result} \mathrm{highlights}$ seed moisture as a key parameter to be managed before soybean seed treatment, aiming to maintain a high physiological quality.

\section{Referências Bibliográficas}

ABRASEM. Anuário 2015. Associação Brasileira de Sementes e Mudas. Brasília, DF. 2015. 110 p.

AOSA. ASSOCIATION OF OFFICIAL SEED ANALYSTS. Seed vigor testing handbook. Contribution n. 32., Ithaca, NY. 2009.

BEWLEY, J. D.; BLACK, M. Seeds: physiology of development and germination. $2^{\text {nd }}$ ed. Berlin: Springer Science \& Business media, 2013. 445 p.

BRASIL/MAPA. MINISTÉRIO DA AGRICULTURA, PECUÁRIA E ABASTECIMENTO. Regras para análise de sementes. Secretaria de Defesa Agropecuária. Brasília-DF: MAPA/ACS, 2009. 399 p.

CONAB. COMPANHIA NACIONAL DE ABASTECIMENTO. Acompanhamento da safra brasileira de grãos - dezembro, v. 3, n. 9, 174 p., 2016

DEMITO, A.; AFONSO, A. D. L. Qualidade das sementes de soja resfriadas artificialmente. Engenharia na Agricultura, Viçosa-MG, v. 17, n. 1, p. 7-14, 2009.

ISTA. INTERNATIONAL SEED TESTING ASSOCIATION. International rules for seed testing. Switzerland, 2006. 64 p.

FRANÇA-NETO, J. B.; HENNING, A. A.; KRZYZANOWSKI, F. C.; HENNING, F. A.; LORINI, I. Adoção do tratamento industrial de sementes de soja no Brasil, safra 2014/2015. Informativo Abrates, Londrina-PR, v. 25 , n. 1 , p. $26-29,2015$.

HENNING, A. A.; FRANÇA-NETO, J. B.; KRZYZANOWSKI, F. C.; LORINI, I. Importância do tratamento de sementes de soja com fungicidas na safra 2010/2011, ano de "La niña". Londrina-PR: Embrapa Soja, 2010. 8 p. (Circular Técnica, 82).

MAGUIRE, J. D. Speed of germination aid in selection and evaluation for seedling emergence and vigor. Crop Science, Madison, v. 2, n. 2, p. 176-77, 1962.

MATTHEWS, S.; POWELL, A. Electrical conductivity vigour test: physiological and basis use. Seed Testing International, Zurich, v. 1, n. 131, p. 32-35, 2006.

MBOFUNG, G. C. Y.; GOGGI, S. A.; LEANDRO, L. F. S.; MULLEN, R. E. Effects of storage temperature and relative 
humidity on viability and vigor of treated soybean seeds. Crop Science, Madison, v. 53, p. 1086-1095, 2013.

SCOTT, J. M. Seed coatings and treatments and their effects on plant establishment. In: BRADY, N., C. (Ed.). Advances in Agronomy, Armidale: Academic Press, 1998. 452 p.

SEGALIN, S. R.; BARBIERI, A. P. P.; HUTH, C.; BECHE, M.; MATTIONI, N. M.; MERTZ, L. M. Physiological quality of soybean seeds treated with different spray volumes. Journal of Seed Science, Londrina-PR, v. 35, n. 4, p. 501509, 2013.

VIRGOLINO, Z. Z.; RESENDE, O.; GONÇALVES, D. N.; MARÇAL, K. A. F.; SALES, J. F. Physiological quality of soybean seeds artificially cooled and stored in different packages. Revista Brasileira de Engenharia Agrícola e Ambiental, Campina Grande-PB, v. 20, n. 5, p. 473-480, 2016.

ZUCHI, J.; LACERDA-FILHO, A. F. Esfriamento dinâmico de sementes de soja. Informativo Abrates, Londrina-PR, v. 21, n. 3, p. 30-34, 2011.

ZUCHI, J.; FRANÇA-NETO, J. B.; SEDIYAMA, C. S.; LACERDA-FILHO, A. F.; REIS, M. S. Physiological quality of dynamically cooled and stored soybean seeds. Journal of Seed Science, Londrina-PR, v. 35, n. 3, p. 353-360, 2013. 